\title{
Nutritional Characteristics of High Yielding Exotic Grasses for Seeding Cleared South Texas Brushland
}

\author{
P.F. McCA WLEY AND B.E. DAHL
}

\begin{abstract}
Three exotic grasses potentially useful converting south Texas brush rangeland to permanent pasture were evaluated in 1976 and 1977. Yearling cattle required 16.6, 23.1, and $34.8 \mathrm{~kg}$ of forage per kg of gain for coastcross-1 bermudagrass, kleingrass-75, and Bell rhodesgrass, respectively. Cattle gained $0.68,0.56$, and 0.33 $\mathrm{kg} / \mathrm{head}$ daily grazing these species. They ate (forage disappearing) about $12 \mathrm{~kg} / \mathrm{head}$ daily regardless of species, so daily gains directly reflected differences in quality among the forages. Our data suggest that the quality measure most nearly deficient was the factor most limiting animal performance, e.g., correlation between average daily gain and $P$ content was $\boldsymbol{r}=\mathbf{0 . 8 9}$ for cattle grazing Bell rhodesgrass. Its $P$ content varied from 0.16 to $0.06 \%$ from spring to fall compared to 0.24 to $0.15 \%$ from spring to fall for the other two forages. Overall, 24-hr IVDMD (fermentation only) best correlated with animal daily gain. Generally, Bell rhodegrass had lowest, coastcross-1 bermudagrass highest, and kleingrass- 75 intermediate quality values, particularly for digestibility, crude protein, and digestible energy. Dry matter yields were 9.6, 11.6, and 11.8 thousand $\mathrm{kg} / \mathrm{ha}$ for coastcross-1 bermudagrass, kleingrass-75, and Bell rhodesgrass in 1976.
\end{abstract}

Conversion of dense brush rangeland to permanent pasture has been an economically efficient practice for beef producers in South Texas (Carter 1958). However, to intelligently select a suitable forage species for seeding, one needs to evaluate both relative yield and quality among usable species.

Three exotic grasses currently are popular for use on fine-textured, clay-pan soils of South Texas. Kleingrass selection-75 (Panicum coloratum) is the most popular, because it is well adapted, reportedly high in quality, potentially palatable all year, high in production, and produces seed eaten by birds. Bell rhodesgrass (Chloris gayana), an early grower resistent to rhodesgrass scale, has been commonly grown. It is attractive to ranchers as it has good seedling vigor, greens up in spring, and has a high yield. Some ranchers report that it tends to disappear in 3 or 4 years. Coastcross-1 bermudagrass (Cynodon dactylon) is one of the most nutritious grasses available (Duble 1970). Some users report that it is less drought tolerant than coastal bermudagrass and that it is a poor producer after 4 or 5 years.

Because each species has attributes desired by South Texas ranchers, it was deemed necessary that the three species be compared under similar conditions so one could more intelligently choose among them as a seeding choice

\footnotetext{
Authors are research assistant and professor, Range and Wildlife Management, Texas Tech University, Lubbock. P.F. McCawley is now a graduate research assistant, Department of Renewable Resources, University of Arizona, Tucson.

This paper is publication number T-9-213 of the College of Agricultural Sciences, Texas Tech University. Research was conducted on the P.H. Welder Ranch, Sinton, Texas. Mr. Welder's cooperation and support are gratefully acknowledged. Manuscript received May 1, 1979.
}

following mechanical brush clearing.

This paper compares the nutritional attributes of these three grasses grown on clay-pan soils typical of much brush infested rangeland in the Coastal Bend of South Texas. Also, yearling cattle performance is related to quality differences among these grasses.

\section{Materials and Methods}

This study was conducted on a ranch $8 \mathrm{~km}$ north of Sinton in the Texas Coastal Bend. The region is subtropical with warm, humid summers and short, mild winters. Average annual precipitation is $76 \mathrm{~cm}$ and the growing season is 335 days (Gould and Box 1969).

During 1972 and 1973, 360 ha of rangeland infested with mesquite (Prosopis glandulosa) and blackbrush acacia (Acacia rigidula) was rootplowed and raked. Test grasses were established on the cleared rangeland from 1972 to 1974 . To evaluate their effect on cattle weight gains, 1.8- to 2.0-ha test plots were fenced for grazing comparisons. Plots in the coastcross (coastcross-1 bermudagrass) and klein (kleingrass selection-75) plantings were grazed in 1974 and 1975. Bell rhodes (Bell rhodesgrass) plots were fenced in 1976. Also, yield and dry matter disappearance were first measured on plantings in 1976.

During 1975 five yearling steers grazed continuously from May 1 to December 2 on each 1.8-ha test plot. In 1976, a grazing system was established whereby test plots were quartered and yearling heifers grazed in rotation 2-weeks on each quarter from April 26 to October 15. Animal performance was measured as average daily gain (ADG) determined from bi-weekly weighings. Stocking rates were periodically adjusted according to relative pasture utilization. Hand-plucked samples to simulate diets were collected from each test plot bi-weekly from July to December in 1975 and from March to November in 1976. Samples were analyzed for 24 and $48-\mathrm{hr}$ in vitro dry matter digestibility (IVDMD) using a modified TilleyTerry technique (USDA 1970). A 24-hr in vitro fermentation only was included because we believed it to be a better measure to compare nutritive value among forages than the standard $48-\mathrm{hr}$ two stage Tilley and Terry procedure. Minson and Milford (1967) found that 12 -hr fermentation in IVDMD trials were more highly correlated with dry matter intake of rhodesgrass than other fermentation periods tested. Engles et al. (1970) reported that the 48-hr, two stage technique was best correlated to dry-matter intake, and the 24-hr fermentation only was the best predictor of overall quality.

Digestible energy (DE) was calculated from 48-hr organic matter digestibility (IVOMD) coefficients determined according to USDA (1970). Crude protein (CP) was evaluated through microKjeldahl techniques (AOAC 1970). Measurements of carotene were made according to Goodwin (1955), and phosphorous content $(\mathrm{P})$ was determined by a colorimetric vanadomolybdate indicator procedure (AOAC 1970). Organic matter (OM) was measured as weight loss following high temperature combustion, and moisture content following $48 \mathrm{hr}$ drying at $55^{\circ} \mathrm{C}$.

Forage production and disappearance was determined in 1976 
only. Twelve exclosure cages were used per test plot. Grasses of each test species were clipped to a $1.5-\mathrm{cm}$ stubble height in 3 paired $0.45 \mathrm{~m}^{2}$ plots per quarter pasture following each rotation of the heifers. Nutritional values for diet collection dates were correlated with corresponding ADG values.

Early forage $\mathbf{P}$ analyses indicated low tissue $\mathbf{P}$ in Bell rhodes relative to that of the other grasses. To insure these differences were not soil related, soil samples were collected at 10 and $75 \mathrm{~cm}$ depths in 1976. Soil $P$ in Bell rhodes plots was as high as in the other two plots.

Statistical analyses were performed according to standard analysis of variance procedures. Sources of variation were: species (3), years (2), dates within years (from 9 to 11), animals/ seeded species (5 to 6), and forage yield samples/date (3). Hand-plucked simulated diet samples were collected 3 times each season for each species.

\section{Results and Discussion}

Seasonal gains from yearlings were not different $(P<0.05)$ between those grazing coastcross or klein in 1975 or 1976. In 1975 , yearlings gained 260 and $285 \mathrm{~kg} / \mathrm{ha}$, respectively. The coastcross plots allowed 534 steer days/ha compared to 586 for the klein plots. In 1976, yearling heifers gained 290 and $280 \mathrm{~kg} / \mathrm{ha}$, respectively. However, heifers grazing Bell rhodes gained only $180 \mathrm{~kg} / \mathrm{ha}$ during the same period. Heifer days/ ha were 433,502 , and 541 for coastcross, klein, and Bell rhodes, respectively.

Quality between years for either klein or coastcross was not different $(P<0.05)$ for the in vitro digestibility values, DE or OM. P and CP values were lower $(P<0.05)$ for 1976 than for 1975. Because ADG was better related to the digestibility values and because the 1976 values for $C P$ and $P$ were consistently lower for both species in 1976 (i.e. no seasonnutrient interaction) detailed discussion of nutrient evaluation is limited to the 1976 data where all species were represented. As expected, forage quality of all species decreased with advancing maturity, as did ADG. Correlation $(P<0.01)$ between nutritional characteristics and ADG for animals grazing all species in 1976 were highest for 24-hr $\operatorname{IVDMD}(r=0.75)$, percent $\mathrm{OM}(=0.69)$, and $P(r=0.62)$.

\section{Pasturing Efficiency among Test Forages}

Efficiency in pasturing (i.e. forage:gain conversion ratio) probably best measures relative forage values to grazing animals. Quantity as well and quality for forage determines efficiency (Hyder 1967). Other studies in south and east Texas with forages similar to those used in this study showed gain/animal related to forage availability within forage digestibility groupings. With low digestible dry matter, cattle made acceptable gains only with large amounts of available forage. They produced acceptable gains with lesser amounts of available forage when the forage was higher in digestibility (Riewe 1976; Duble 1970). Riewe (1976) found steers grazing Gulf ryegrass at Angleton, Texas, gained less than optimum with less than about $1,350 \mathrm{~kg} /$ ha of available forage. Using this criterion, quantity was never limiting for our study as available forage from all pastures exceeded $1,350 \mathrm{~kg} / \mathrm{ha}$ and utilization never exceeded $45 \%$ (i.e. a moderate utilization level) until near the end of the season (Table 1).

In this study, yearling cattle gained most efficiently on coastcross and least efficiently on Bell rhodes. Forage required per $\mathrm{kg}$ of gain for the season was 16.6, 23.1, and $34.8 \mathrm{~kg}$ for coastcross, klein, and Bell rhodes grasses, respectively (Table 1). As the forage used (disappearing) per head
Table 1. Yield, utilization, daily gains/yearling heifer, and pasturing effciency by season in 1976 for the three test species.

\begin{tabular}{|c|c|c|c|c|c|c|}
\hline (1976) & Species ${ }^{\prime}$ & $\begin{array}{l}\text { Forage } \\
\text { conver- } \\
\text { sion rate } \\
(\mathrm{kg} / \mathrm{kg})\end{array}$ & $\begin{array}{l}\text { Daily } \\
\text { gain } \\
\text { /hd } \\
(\mathbf{k g})\end{array}$ & $\begin{array}{l}\text { Daily } \\
\text { forage } \\
\text { disapp. } \\
\text { /hd } \\
\text { (kg) }\end{array}$ & $\begin{array}{l}\text { Yield } \\
\text { (DM) } \\
\text { (kg/ha) }\end{array}$ & $\begin{array}{l}\text { Utiliza- } \\
\text { tion } \\
(\%)\end{array}$ \\
\hline $\begin{array}{l}\text { Apr. } 26 \\
\text { to } \\
\text { July } 3\end{array}$ & $\begin{array}{l}\text { CC-1 } \\
\mathrm{K}-75 \\
\text { Brh }\end{array}$ & $\begin{array}{l}12.0 \\
15.0 \\
23.3\end{array}$ & $\begin{array}{l}0.66 \\
0.86 \\
0.51\end{array}$ & $\begin{array}{r}8.0 \\
13.0 \\
11.8\end{array}$ & $\begin{array}{l}4210 \\
7250 \\
7080\end{array}$ & $\begin{array}{l}39 \\
38 \\
38\end{array}$ \\
\hline $\begin{array}{l}\text { July } 3 \\
\text { to } \\
\text { Aug. } 23\end{array}$ & $\begin{array}{l}\text { CC-1 } \\
\text { K-75 } \\
\text { Brh }\end{array}$ & $\begin{array}{r}22.6 \\
41.0 \\
144.7\end{array}$ & $\begin{array}{l}0.66 \\
0.30 \\
0.07\end{array}$ & $\begin{array}{l}15.0 \\
12.4 \\
10.3\end{array}$ & $\begin{array}{l}3880 \\
2650 \\
3170\end{array}$ & $\begin{array}{l}37 \\
45 \\
43\end{array}$ \\
\hline $\begin{array}{l}\text { Aug. } 23 \\
\text { to } \\
\text { Oct. } 15\end{array}$ & $\begin{array}{l}\text { CC-1 } \\
\text { K-75 } \\
\text { Brh }\end{array}$ & $\begin{array}{l}19.7 \\
39.3 \\
35.5\end{array}$ & $\begin{array}{l}0.72 \\
0.35 \\
0.34\end{array}$ & $\begin{array}{l}14.3 \\
13.8 \\
12.0\end{array}$ & $\begin{array}{l}1500 \\
1680 \\
1510\end{array}$ & $\begin{array}{l}51 \\
56 \\
52\end{array}$ \\
\hline Season & $\begin{array}{l}\text { CC-1 } \\
\text { K-75 } \\
\text { Brh }\end{array}$ & $\begin{array}{l}16.6 \\
23.1 \\
34.8\end{array}$ & $\begin{array}{l}0.68 \\
0.56 \\
0.33\end{array}$ & $\begin{array}{l}11.2 \\
12.9 \\
11.4\end{array}$ & $\begin{array}{r}9600 \\
11570 \\
11760\end{array}$ & $\begin{array}{l}51 \\
56 \\
52\end{array}$ \\
\hline
\end{tabular}

ICC-1 = coastcross- 1 bermudagrass; $\mathrm{K}-75=$ kleingrass selection $75 ; \mathrm{Brh}=$ Bell rhodesgrass.

daily was about $12 \mathrm{~kg}$ for all pastures (Table 1), daily gains directly reflected differences in quality among the forages. Also, stocking pressure was maintained at approximately the same level for all test plots. For coastcross, klein, and Bell rhodes stocking pressure was 22.2, 23.1, and 21.8 $\mathrm{kg} /$ heifer/day, respectively.

Because coastcross is a non-seeding hybrid and remains vegetative, it apparently has a quality advantage due to a higher proportion of leaves. Both klein and Bell rhodes grasses grew more rapidly in spring and it was difficult to stock heavily enough to prevent their producing reproductive shoots. By May 27, they had produced 63 and $60 \%$, respectively, of their total season yield compared to only 44\% for coastcross. Despite similar growth forms and growth patterns, klein maintained much higher quality attributes than Bell rhodes. This resulted in less use per head of the Bell rhodes throughout the season. When animals consume poorer quality forage and combine this with less

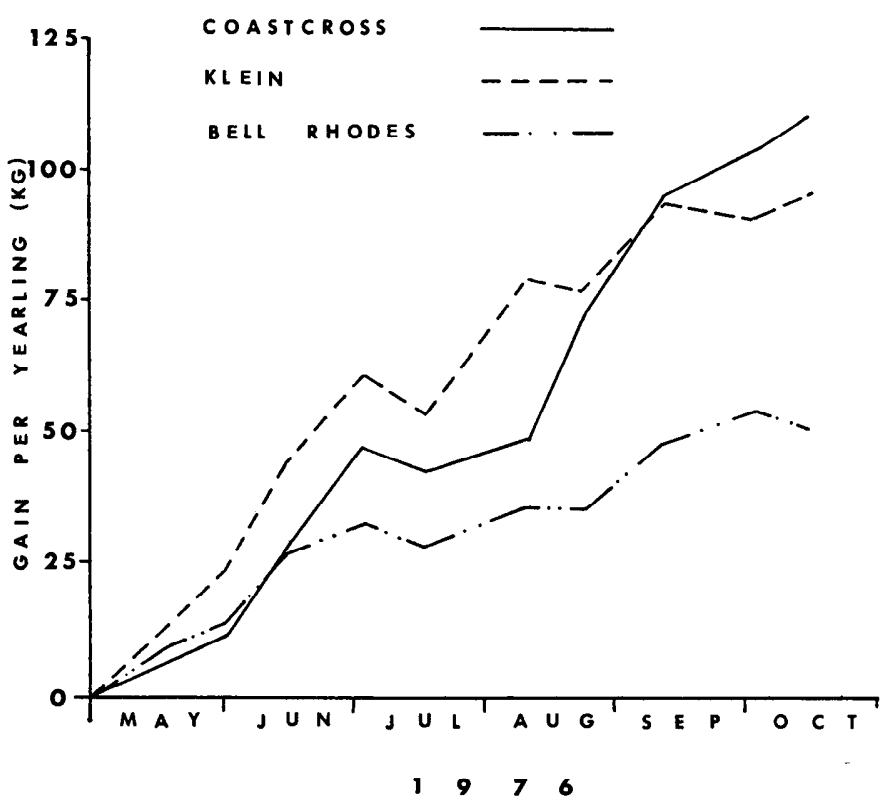

Fig. 1. Cumulative gains per yearling heifer on coastcross-1 bermudagrass, kleingrass, and Bell rhodesgrass in 1976. 
Table 2. Seasonal IVDMD (\% of DM) of three grasses in south Texas.

\begin{tabular}{lccc}
\hline \hline Season & $\begin{array}{c}\text { Coastcross-1 } \\
\text { bermudagrass* }\end{array}$ & Kleingrass-75 & Bell rhodesgrass \\
\hline 24-hr IVDMD & & & \\
Spring** & $41.7_{\mathrm{a}}^{\mathrm{A}}$ & $42.6_{\mathrm{a}}^{\mathrm{A}}$ & $42.3_{\mathrm{a}}^{\mathrm{A}}$ \\
Early summer & $41.5_{\mathrm{a}}^{\mathrm{A}}$ & $39.1_{\mathrm{ab}}^{\mathrm{B}}$ & $39.2_{\mathrm{ab}}^{\mathrm{B}}$ \\
Late summer & $39.5_{\mathrm{a}}^{\mathrm{A}}$ & $39.3_{\mathrm{ab}}^{\mathrm{A}}$ & $37.4_{\mathrm{ab}}^{\mathrm{A}}$ \\
Fall & $34.9_{\mathrm{a}}^{\mathrm{A}}$ & $31.6_{\mathrm{b}}^{\mathrm{A}}$ & $31.4_{\mathrm{b}}^{\mathrm{A}}$ \\
Average & $39.4^{\mathrm{A}}$ & $38.1^{\mathrm{A}}$ & $37.6^{\mathrm{A}}$ \\
48-hr IVDMD & & & \\
Spring & $53.5_{\mathrm{a}}^{\mathrm{A}}$ & $52.9_{\mathrm{a}}^{\mathrm{A}}$ & $56.4_{\mathrm{a}}^{\mathrm{A}}$ \\
Early summer & $48.0_{\mathrm{ab}}^{\mathrm{A}}$ & $49.9_{\mathrm{ab}}^{\mathrm{A}}$ & $46.1_{\mathrm{b}}^{\mathrm{A}}$ \\
Late summer & $46.3_{\mathrm{b}}^{\mathrm{A}}$ & $42.1_{\mathrm{bc}}^{\mathrm{B}}$ & $39.4_{\mathrm{b}}^{\mathrm{B}}$ \\
Fall & $43.5_{\mathrm{b}}^{\mathrm{A}}$ & $36.3_{\mathrm{c}}^{\mathrm{A}}$ & $36.4_{\mathrm{c}}^{\mathrm{A}}$ \\
Average & $47.8^{\mathrm{A}}$ & $45.3^{\mathrm{AB}}$ & $44.6^{\mathrm{B}}$ \\
\hline
\end{tabular}

*Values in the same column followed by the same lowercase letters are not significantly different at $P<0.05$ level.

${ }^{* *}$ Values in the same row followed by the same capital letter are not significantly different at $P<0.05$ level.

intake, inevitably they gain less; in this case only 0.33 $\mathrm{kg}$ / head daily vs 0.56 for klein and 0.68 for coastcross. Heifer gains on Bell rhodes were lower throughout the season (Fig. 1).

\section{Digestibility}

Coastcross had consistently higher digestibility coefficients than the other two grasses studied. However, only in the early summer was it significantly $(<0.05)$ more digestible (Table 2). Duble (1970) found that small variations in IVDMD caused significant changes in voluntary intake, thus affecting animal performance. Similarly our data showed, with few exceptions, that yearlings grazing Bell rhodes consistently gained less than cattle grazing the other species (Fig. 1). Except for the early part of the growing season, yearlings grazing Bell rhodes consumed less forage/hd daily compared to those grazing coastcross or klein (Table 1).

While not as well correlated to ADG as $24 \mathrm{hr}$ IVDMD (Table 3 ), the $48 \mathrm{hr}$ fermentation only IVDMD values were more useful for dramatizing among species digestibility changes through the year. Table 2 shows that digestibility of coastcross declined only $19 \%$ from spring to fall, whereas, digestibility of klein and bell rhodes declined $31 \%$ and $35 \%$, respectively. Olubajo et al. (1974) also found that coastcross maintained relatively high digestibility throughout the grazing season. Reid et al. (1973) demonstrated large decreases in klein digestibility as the growing season progressed. Bell rhodes digestibilities were similar to those reported by Min-

Table 3. Correlation coefficients $(r)$ between animal gain and individual nutrients for three grasses in south Texas.

\begin{tabular}{lccc}
\multicolumn{1}{c}{ nutrients for three grasses in south Texas. } \\
\cline { 2 - 4 } $\begin{array}{l}\text { Effect on ADG }(r) \\
\text { Independent variablc }\end{array}$ & $\begin{array}{c}\text { Coastcross-1 } \\
\text { bermudagrass Kleingrass-75 }\end{array}$ & $\begin{array}{c}\text { Bell } \\
\text { rhodesgrass }\end{array}$ \\
\hline Crude protein & 0.40 & 0.34 & 0.75 \\
$\begin{array}{l}\text { 24-hr in vitro dry matter } \\
\text { digestibility }\end{array}$ & 0.64 & 0.77 & 0.86 \\
48-hr in vitro dry matter & & & \\
digestibility & 0.53 & 0.72 & 0.70 \\
48-hr in vitro organic matter & & & \\
digestibility & 0.59 & 0.73 & 0.69 \\
$\begin{array}{l}\text { Digestible energy } \\
\text { Phosphorus }\end{array}$ & 0.59 & 0.72 & 0.69 \\
Carotene & 0.77 & 0.54 & 0.89 \\
Organic matter & 0.19 & 0.25 & 0.45 \\
\hline
\end{tabular}

son and Milford (1967) who found that seasonal digestibility declines corresponded to increased voluntary intake and less animal gain.

\section{Organic Matter}

Although organic matter is seldom, if ever, reported as a quality item in forage evaluation, it apparently has a place and it is easily obtained. In this study, it was one of the most highly correlated variables to ADG (Table 3). Klein had highest OM among the grasses studied (Table 4). Highest OM coincided with peak growth rates and with the highest ADG period. This peak occurred in May for all species and again in August-September for coastcross. All grasses lost $\mathrm{OM}$ in late fall, corresponding to the period of highest nutrient translocation to the roots prior to winter (Trlica 1977). Because no established standards are available for $\mathrm{OM}$, no significance is attached to these findings, except that as $\mathrm{OM}$ declines, digestibility usually declines also. However, correlation ( $r$ ) between OM and IVDMD fluctuated from 0.41 to 0.86 , which was a poorer relationship than expected.

\section{Phosphorus}

Overall, $\mathrm{P}$ was the third most highly correlated forage quality measure to ADG but it was the best correlated to ADG for heifers grazing Bell rhodes (Table 3 ). The influence of $\mathbf{P}$ on ADG for cattle grazing Bell rhodes reflects the $\mathbf{P}$ deficiency, which was apparent even early in the season for this grass. Forage $P$ content progressively decreased as the grass matured. Bell rhodes had less $P$ than coastcross in all seasons, and it had less $P$ than klein from early summer

Table 4. Seasonal content of selected quality attributes of three grasses in south Texas.

\begin{tabular}{|c|c|c|c|}
\hline Season & $\begin{array}{r}\text { Coastcross-1 } \\
\text { bermudagrass* }\end{array}$ & Kleingrass-75 & Bell rhodesgrass \\
\hline \multicolumn{4}{|c|}{ Organic matter (\% of DM) } \\
\hline Spring ** & $92.3_{a}^{A}$ & $93.4_{\mathrm{a}}^{\mathrm{A}}$ & $89.5_{\mathrm{a}}^{\mathrm{A}}$ \\
\hline Early summer & $91.1_{\mathrm{a}}^{\mathrm{B}}$ & $93.5_{\mathrm{a}}^{\mathrm{A}}$ & $91.7_{\mathrm{a}}^{\mathrm{B}}$ \\
\hline Late summer & $92.8_{\mathrm{a}}^{\mathrm{A}}$ & $93.1_{a}^{A}$ & $90.0_{\mathrm{a}}^{\mathrm{B}}$ \\
\hline Fall & $87.7_{\mathrm{a}}^{\mathrm{A}}$ & $91.3_{\mathrm{a}}^{\mathrm{A}}$ & $88.3_{\mathrm{a}}^{\mathrm{A}}$ \\
\hline Average & $90.8^{\mathrm{B}}$ & $92.8^{\AA}$ & $89.9^{\mathrm{B}}$ \\
\hline \multicolumn{4}{|c|}{ Phosphorus (\% of DM) } \\
\hline Spring & $0.24_{a}^{\mathrm{A}}$ & $0.21_{\mathrm{a}}^{\mathrm{AB}}$ & $0.16_{\mathrm{a}}^{\mathrm{B}}$ \\
\hline Early summer & $0.22_{\mathrm{a}}^{\mathrm{A}}$ & $0.19_{\mathrm{a}}^{\mathrm{A}}$ & $0.12_{\mathrm{ab}}^{\mathrm{B}}$ \\
\hline Late summer & $0.22_{\mathrm{a}}^{\mathrm{A}}$ & $0.15_{\mathrm{a}}^{\mathrm{B}}$ & $0.11_{\mathrm{b}}^{\mathrm{C}}$ \\
\hline Fall & $0.15_{\mathrm{a}}^{\mathrm{A}}$ & $0.16_{\mathrm{a}}^{\mathrm{A}}$ & $0.06_{\mathrm{c}}^{\mathrm{B}}$ \\
\hline Average & $0.21^{\mathrm{A}} \mathrm{A}$ & $0.18^{\mathrm{B}}$ & $0.11^{\mathrm{C}}$ \\
\hline \multicolumn{4}{|c|}{ Crude protein (\% of DM) } \\
\hline Spring & $13.3_{\mathrm{a}}^{\mathrm{A}}$ & $12.8_{\mathrm{a}}^{\mathrm{A}}$ & $11.3_{\mathrm{a}}^{\mathrm{A}}$ \\
\hline Early summer & $11.5_{\mathrm{a}}^{\mathrm{A}}$ & $9.4_{\mathrm{ab}}^{\mathrm{AB}}$ & $8.6_{\mathrm{ab}}^{\mathrm{B}}$ \\
\hline Late summer & $9.2_{\mathrm{ab}}^{\mathrm{A}}$ & $8.9 \mathrm{~A}$ & $8.4_{\mathrm{ab}}^{\mathrm{A}}$ \\
\hline Fall & $7.0 \mathrm{~A}$ & $8.5_{\mathrm{b}}^{\mathrm{A}}$ & $6.8 \mathrm{~b}$ \\
\hline Average & $10.2^{\mathrm{A}}$ & $9.9^{\mathrm{A}}$ & $8.8^{\mathrm{A}}$ \\
\hline \multicolumn{4}{|c|}{ Digestible energy (Mcal/kg DM) } \\
\hline Spring & $2.02_{\mathrm{a}}^{\mathrm{A}}$ & $1.99_{\mathrm{a}}^{\mathrm{A}}$ & $1.89_{\mathrm{a}}^{\mathrm{A}}$ \\
\hline Early summer & $1.70_{\mathrm{ab}}^{\mathrm{A}}$ & $1.86_{a}^{\mathrm{A}}$ & $1.61_{\mathrm{b}}^{\mathrm{A}}$ \\
\hline Late summer & $1.60_{\mathrm{b}}^{\mathrm{A}}$ & $1.50_{\mathrm{b}}^{\mathrm{AB}}$ & $1.30_{\mathrm{c}}^{\mathrm{B}}$ \\
\hline Fall & $1.34_{\mathrm{b}}^{\mathrm{A}}$ & $1.18_{\mathrm{c}}^{\mathrm{A}}$ & $1.19_{\mathrm{c}}^{\mathrm{A}}$ \\
\hline Average & $1.66^{\mathrm{A}}$ & $1.63^{\mathrm{AB}}$ & $1.50^{\mathrm{B}}$ \\
\hline
\end{tabular}

*Values in the same column followed by the same lowercase letter are not significantly different at $P<0.05$ level.

**Values in the same row followed by the same capital letter are not significantly different at $P<0.05$ level. 
through fall. This indicates a quantitatively lesser ability of Bell rhodes to extract soil $P$ from the clay-pan soils typical of the Texas coastal bend. Long et al. (1969) determined P contents of rhodesgrass in Uganda that ranged from 0.02 to $0.34 \%$. In his research, forage $P$ was highly dependent $(P<0.001)$ on soil $\mathrm{P}$ in sandy loams and sandy clay loams. Also, on all sites where dietary $P$ failed to meet N.R.C. (1970) recommendations, bermudagrass and Panicum maximum exceeded the recommended minimum $0.18 \%$ level.

Coastcross provided adequate dietary $\mathbf{P}$ for good cattle gain through early October and as $\mathbf{P}$ declined so did ADG. Klein $P$ in 1976 mostly fluctuated between 0.15 and $0.21 \%$ without distinct seasonal patterns, which accounted for the low P correlation with ADG (Table 3).

\section{Crude Protein}

Forage $\mathrm{CP}$ is traditionally the nutrient used most to predict livestock performance. However, its correlation coefficient with ADG was only 0.41 for this study. Van Soest (1965) credited the relationship between protein and intake to be responsible for correlated rates of gain. Thornton et al. (1968) cites the relationship between CP and digestibility as causative. Barton (1976) reported that small changes in protein content of coastcross had a major influence on intake. In our study $C P$ correlated $(P>0.05)$ well with 24 hour IVDMD in Bell rhodes $(r=0.73)$ and with 48-hour IVDMD in coastcross $(r=0.71)$. However, the digestibility values for all species were much better correlated to ADG (Table 3) than was CP. Decline in CP from spring to fall was 47, 40, and $34 \%$ for coastcross, Bell rhodes, and klein, respectively.

\section{Digestible Energy}

Energy is considered one of the factors most limiting cattle performance along the U.S. Gulf Coast (Riewe 1976). According to N.R.C. (1970), growing $300-\mathrm{kg}$ cattle would need $2.51 \mathrm{Mcal} / \mathrm{kg}$ of DE from the forage for optimum gains. The grasses we studied seldom had over $2.2 \mathrm{Mcal} / \mathrm{kg}$ $\mathrm{DM}$ of $\mathrm{DE}$ and that declined to about $1.0 \mathrm{Mcal} / \mathrm{kg}$ by mid-fall. Nevertheless, consumption (disappearance) was high enough that heifers made acceptable gains (Table 1). Coastcross had highest DE and Bell rhodes the lowest among our grasses (Table 4), and heifer gains reflected these differences in energy. According to Riewe (1976), warmseason perennial grasses are lower in DE than any other group of forages and cannot be considered "high quality".

\section{Carotene}

Carotene as the source of vitamin A for grazing animals has received considerable attention as a measure of forage quality in the more arid rangelands. Also, we have found carotene content a useful guide to relatively preference among species on unseeded native range (Dahl, unpublished data). In this study, carotene bore no relation $(P<0.05)$ to ADG. Among the grasses studied klein tended to have higher carotene than the other two.

\section{Conclusions}

As with the "law of the minimum" conceived by Justis Liebig, this study showed that the measure of forage quality most nearly deficient was the quality factor most limiting animal performance. In every quality attribute measured, Bell rhodes had lowest (most nearly deficient) values. Consequently, ADG of yearlings grazing Bell rhodes was most highly correlated to the quality attributes measured and ADG of those yearlings grazing coastcross was least corre- lated to these attributes (Table 3).

In comparing quality attributes among the three species, the most disturbing feature was low phosphorus content of Bell rhodes (Table 4). This selection of rhodegrass is grown in South Texas primarily because it is relatively resistant to rhodegrass scale. Although not reported in literature, conceivably the factor making this plant undesirable to the scale insect and less desirable to grazing cattle is low phosphorus content. A fertilizer study that accompanied this study indicated that as little as $45 \mathrm{~kg} \mathrm{P}_{2} \mathrm{O}_{5} /$ ha/ year could correct the phosphorus deficiency (Dahl, unpublished data). However, it remains to be proven whether either phosphorus fertilizer or a phosphorus diet supplement could increase pasturing efficiency sufficiently to make this high producing grass comparable to other forages available for rangeland plantings in Texas. We suggest that land managers should certainly look into fertilizer or supplementation before destroying existing high producing Bell rhodes stands in favor of higher quality forages yet to be planted.

These grasses were established from 1972 to 1974 and none of them showed signs of stand deterioration as of late summer in 1978. Thus relative longevity may not be a major criterion for selecting one species over the other in this area.

\section{Literature Cited}

Association of Official Agricultural Chemists. 1970. Official methods of analysis. AOAC Washington, D.C. 1015 p.

Barton, F.E., II, H.E. Amos, D. Burdick, and R.L. Wilson. 1976. Relationship of chemical analysis to in vitro digestibility for selected tropical and temperature grasses. J. Anim. Sci. 43: 504.

Carter, M.G. 1958. Reclaiming Texas brushland. J. Range Manage. 11: 1.

Duble, R.L. 1970. Nutritive value and grazing comparison of weeping lovegrass and other summer grasses. In: Proceedings of the First Weeping Lovegrass Symposium, Ardmore, Oklahoma. 205 p.

Engels, E.A.N., A.VanSchalkwyk, P.J. Niemann, and J.A.Swart. 1970. In vitro digestibility of forages as an indication of nutritive value. Nutr. Abst. and Rev. 42: 1161 .

Goodwin, T.W. 1955. Carotenoids. In: Peach, K. and M.V. Tracey. Methods of Plant Analysis 3: 272.

Gould, F.W., and T.W. Box. 1965. Grasses of the Texas Coastal Bend. Texas A\&M Univ. Press. College Station, Texas. $186 \mathrm{p}$.

Hyder, D.N. 1967. Pounds of forage per pound of beef. In: Proceedings of Fifth Ranch Management Conference. Texas Tech Univ. ICASALS Spec. Report 3: 83-91.

Long, M.E.I., W.K. Ndyanabo, B. Marshal, and D.D. Thornton. 1969. Nutritive value of tropical grasses in Ankole and the Queen Elizabeth National Park, Uganda. IV. Mineral content. Trop. Agr. (Trinidad). 46: 201.

Minson, D.J., and R. Milford. 1967. In vitro and faecal nitrogen techniques for predicting the intake of Chloris gayana. J. Brit. Grassl. Soc. 22: 170.

N.R.C. 1970. Nutrient requirements of domestic animals. No. 4. Nutrient requirements of beef cattle. Nat. Res. Counc., Washington, D.C.

Olubajo, F.O., P.J. Van Soest, and V.A. Oyenuga. 1974. Comparison and digestibility of four tropical grasses grown in Nigeria. J. Anim. Sci. 38: 194.

Reid, R.L., A.J. Post, F.J. Olsen, and J.S. Mugerwa. 1973. Studies on the nutritional quality of grasses in Uganda. I. Application of in vitro digestibility techniques to species and stage of growth effects. Trop. Agr. (Trinidad) 50:1

Riewe, M.E. 1976. Principles of grazing management. In: Holt, E.C. and R.K. Lewis (eds.). Grasses and legumes in Texas-development production and utilization. Tex. Agr. Exp. Sta. Res. Monogr. 6: 208-259.

Thornton, D.D., M.E.I. Long, and B. Marshal. 1968. Nutritive value of grasses in Ankole and the Queen Elizabeth National Park, Uganda. I. Collection sites, soils and grasses. Trop. Agr. (Trinidad). 45: 257.

Trlica, M.J. 1977. Distribution and utilization of carbohydrate reserves in range plants. In: Sosebee, R.E. (ed.), Rangeland Plant Physiology. Soc. Range Manage. Pub. Denver, Colorado.

U.S.D.A. 1970. Forage fiber analyses. U.S.D.A. Agricultural Handbook 379. Washington, D.C.

Van Soest, P.J. 1965. Symposium on factors influencing the voluntary intake of herbage by ruminants: Voluntary intake in relation to chemical compositon and digestibility. J. Anim. Sci. 74: 834. 